\title{
Geospatial Analysis of Soil Characteristics and Sensitivity to Desertification of Some Alluvial Deposits, El Behira Governorate, Egypt
}

\author{
Aly A. Gaafar, Ihab M. Morsy, Haytham M. Yehia 1
}

\begin{abstract}
Geostatistical analysis was carried out to map the spatial distribution of the soil characteristics in GIS environment. The present study aimed to use quantitative method to assess land sensitivity to desertification and produce maps for the study area through coupling geostatistical analysis and Geographic Information System (GIS) for some Alluvial deposits, Kafr EI Dawar District, West Delta, Egypt. The study area is located between $31^{\circ}$ $00^{`}$ and $31^{\circ} 14^{\backslash} \mathrm{N}$ and $29^{\circ} 56^{\backslash}$ and $30^{\circ} 14^{\backslash} \mathrm{E}$ with total area of 36370.9 ha. The agricultural land covers about 30953.1 ha., and the urban area occupy about 5417.8 ha. To categorize soil properties, eighty five surface soil samples were collected, and soil samples were prepared and analyzed for chemical and physical characterization. The results of spatial variability and dependence indicated that the best fitted semi-variogram models were the gaussian model for soil salinity and soil depth, and the spherical model for sodium adsorption ratio and clay content. The Environmental Sensitivity Area Index (ESAI) was calculated using the overlaying technique of the different quality indices maps, which allow identifying the links between those indices and their spatial patterns. ESA analysis showed that $3.24 \%$ of the study area was critical to desertification, $3.12 \%$ was fragile to desertification, where most of the study area $(\mathbf{9 2 . 7 2 \% )}$ ) was Non-affected to desertification. The low quality classes of the ESAI were located at the southwestern part of the study area. The results elucidate that the distribution of ESAI matches the distribution of soil characteristics which were used to calculate the soil quality index. Moreover, irrigation water quality, and management dramatically impact desertification processes. Finally, the study recommended that: i) choosing the suitable spatial and temporal scales, as well as identifying the appropriate parameters, and using appropriate models are essential for correctly identifying and monitoring the ecosystem over long periods of time, to assess the sensitivity to desertification; ii) the assessment of environmental sensitive areas to desertification by coupling geostatistical analysis with modeling in geographic information system is a tool to use by decision-makers involved in the planning of sustainable land uses to identify and resist the desertification hazards.
\end{abstract}

Key words: Desertification, Geostatistical analysis, Environmental sensitive area Index, and Soil quality.

\section{INTRODUCTION}

Soil is essentially a non-renewable resource with potentially rapid degradation rates and extremely slow formation and regeneration processes (Zucca et al.,
2014). The integration between Geographic information system and modeling plays a key role in quantitative studies of soil properties and land evaluation for different land uses. Geostatistical analysis has a special ability to minimize the number of the samples to reduce the time, efforts, and costs. It's recommended that the quantitative approach for determining the sensitivity for desertification should be adopted and applies to the areas were desertification and environmental deterioration is expected (Yehia, et. al., 2013). The multi-source approach combining terrain, lithology, geomorphology and land use, applied to the catchments area of the Laou River, allowed us to identify those arable surfaces which require highest priority interventions for the protection of soil and the reduction of sediment transportation at the dams (Raissouni et. al., 2012). Geostatistical methods were developed to create mathematical models of spatial correlation structures with a variogram as the quantitative measure of spatial correlation (Wagner Lourenco et al. 2010). Land degradation has become a problem of great concern, because it threatens the stability of natural systems and weakens the economy and development of human society (FAO, 2007). Land degradation is a multifactor process resulting from the complex interaction of different elements concerning land policies, water resources, climate, soil, and land use (Wessels et al., 2007; Salvati \& Zitti, 2008; Santini et al., 2010). Desertification is the end state of the process of land degradation (Hill et al., 2008), due to a conjunction of different factors (meteoclimatological, ecological and human), causes a progressive loss of productivity in the involved lands (Geist, 2005). The Mediterranean desertification and land use (MEDALUS) approach (Kosmas et al., 1999) focuses on recognizing Environmentally Sensitive Areas (ESAs) through multifactor approaches. To define the Environmentally Sensitive Area Index (ESAI); vegetation, soil, climate, and management qualities are considered. This approach is simple, robust, widely applicable, and adaptable to new information (Kosmas et al., 1999, 2003; Bakr et al., 2012). The adjusted MEDALUS approach suggested by (Bakr et al., 2012) was applied by adding new parameters, Salinity, to the soil quality index and extending the quality indicators to include irrigation water quality. The present study aimed to use

${ }^{1}$ Soil Salinity and Alkalinity Department, Soils, Water \&

Environment Research Institute, Agricultural Research Center, Egypt.

Received March 1, 2017, Accepted March 30, 2017 
quantitative method to assess and map land sensitivity to desertification, through coupling geostatistical analysis with modeling in Geographic Information System (GIS) for some Alluvial soils at Kafr El Dawar District, West Delta, Egypt.

\section{MATERIALS AND METHODS}

Site Description: The study area is located between $31^{\circ}$ $00^{`}$ and $31^{\circ} 14^{\backslash} \mathrm{N}$ and $29^{\circ} 56^{`}$ and $30^{\circ} 14^{`} \mathrm{E}$ with total area of 36370.9 ha. The agricultural land covers about 30953.1 ha and the urban area occupy about 5417.8 ha. The study area includes Kafr El Dawar District, Behira Governorate, Egypt, as shown in map 1.

Sampling design and analysis: Eighty five surface soil samples were collected from the study area, and all the soil samples augers were dug to a depth of $120 \mathrm{~cm}$ to examine the soil depth. The soil samples location were geo-referenced to UTM coordinate system using a Garmin OREGON 550 global positioning system (GPS) receiver and shown on map (2). The soil samples were prepared and analyzed for some chemical and physical characteristics according to (Page et al., 1982) and (Klute, 1986). Salinity of irrigation water was also determined.

Terrain Analysis: Topographic map sheet (1:25000) of Kafr El Dawar was scanned and digitized using ArcGIS 10.1 to extract contour lines, spot heights, irrigation and drainage canals, as well as main roads as input features. Contour lines and spot heights were input to contour gridder module to generate Digital Elevation Model (DEM). Slope and aspect were then derived using spatial analyst.
Descriptive statistical analysis: Statistical analysis was carried out using Excel spreadsheet. The following classical statistics parameters were calculated: minimum, maximum, mean, standard deviation and coefficient of variation of each soil characteristics according to (Webster, 1977) and (Wilding and Dress, 1983).

\section{Geostatistical analysis}

The Semi-Variogram: The semi-variogram is the most important tool in geostatistical applications to soil. It represents the average rate of change of property with distance. It is the basis for modeling the data set and for drawing a contour maps or isarithms according to Burgess and Webster, 1980. The most used variogram models, i.e. Gaussian, Spherical and Exponential were shown below.

\section{Spatial prediction methods:}

Kriging: It is the precise interpolation estimator used to find the best linear unbiased estimate. Ordinary kriging was applied according to (Goovaerts, 1997).

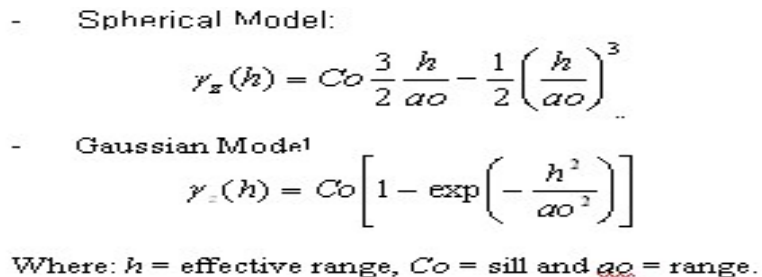

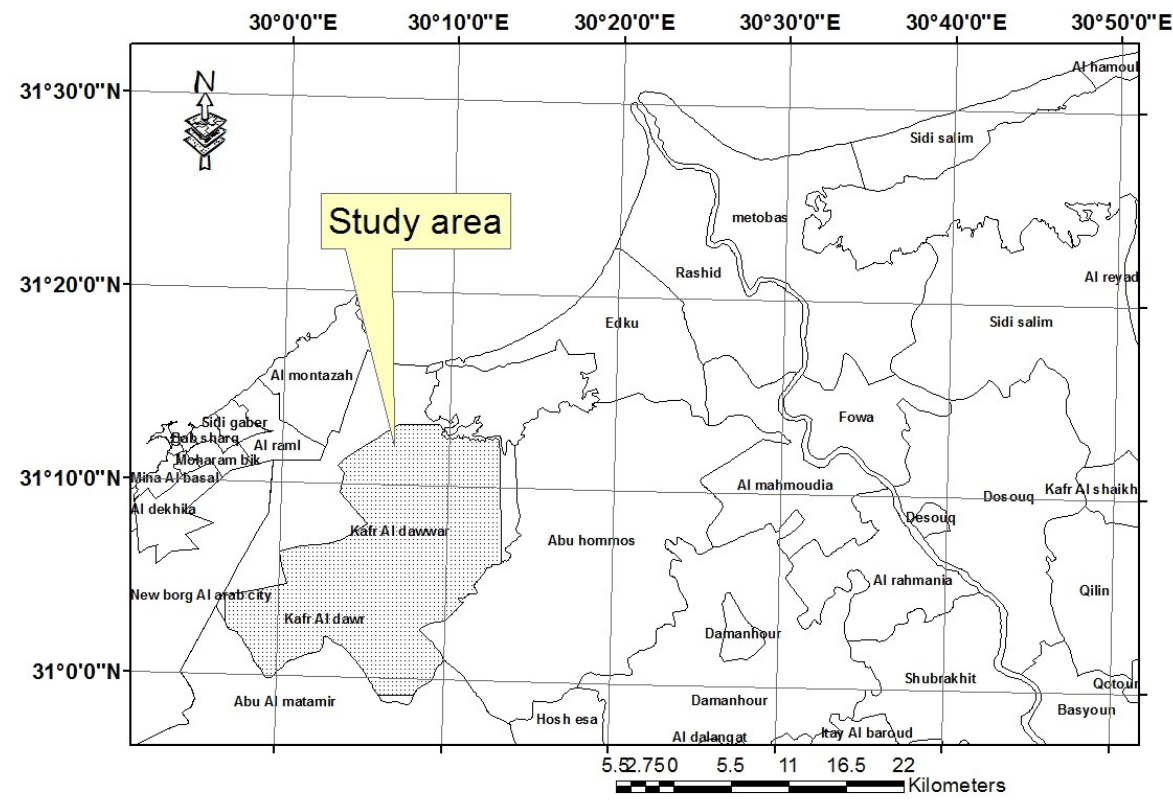

Map 1. General location of the study area 


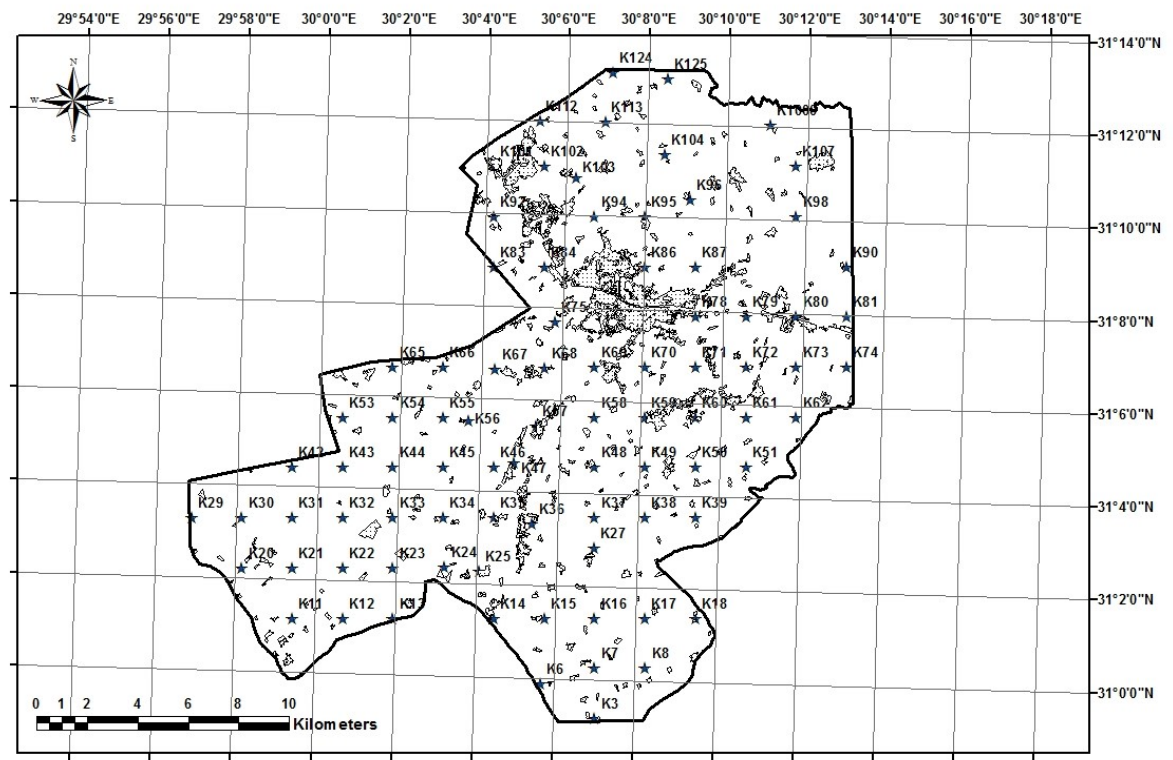

Map 2. Spatial distribution of surface soil samples in the study area

Environmentally Sensitivity Area to Desertification (ESA): The identification of sensitive areas was based on the hypotheses of MEDALUS project model and its adjustment (Bakr et al., 2012). The model applies a geometrical average of some quality indices, in order to provide sensitivity diagnosis. It assumes that each index has only limited capacity of influence the final value of the Environmentally Sensitive Area Index (ESAI) and only when several parameters have a high score, an area can be assigned to high sensitivity class. The following five quality indices were computed; Soil Quality Index (SQI), irrigation water quality index (IWQI), Vegetation Quality Index (VQI), Climatic Quality Index (CQI), and management quality index (MQI). Table (1) shows the thematic indices for the standard MEDALUS approach and its adjustment. The score range for each quality index and final ESAI score are given in Table (2). The main input data for calculating those indices include topographic map of the study area, climatic data derived from the Ministry of Agriculture in addition to soil characteristics and management policy. GIS system (i.e. ArcGIS 10.1) was the main tools for indices interpolation and ESAI mapping.

1. Mapping Soil Quality Index (SQI): Soil is the dominant factor of the terrestrial ecosystems in the arid and semi-arid and dry zones, particularly through its effect on biomass production. Soil quality indicators for mapping ESA's can be related to water availability and erosion resistance (Briggs et al, 1992; Basso et al, 1998). Six soil parameters were considered at the current investigation (i.e. parent material, soil texture, soil depth and slope gradient, salinity, and drainage status). Weighting factors were assigned to each category of the considered parameters on basis of table (1), which were adapted from MEDALUS project methodology (European Commission 1999). The soil Quality Index (SQI) was calculated on basis of equation (1), and classified according to categories shown in table(2). SQI $=($ soil texture $\times$ parent material $\times$ slope $\times$ soil
depth $\times$ drainage $\times$ salinity $)^{1 / 6}$---- $(1)$

2. Mapping irrigation water quality index (IWQI): The new index for irrigation water quality indicator (IWQI) was used based on the salinity of irrigation water as shown by adjusted MEDALUS approach (Table 1).

3. Mapping Vegetation quality index (VQI): Vegetation quality, according to MEDELUS approach is assessed in terms of three aspects. Score values for each of erosion protection, drought resistance and vegetal cover classes were used to calculate VQI based on table (1), while VQI was classified according to the ranges indicated in table (2) using equation (2).

$\mathrm{VQI}=($ erosion protection $\times$ drought resistance $\times$ plant cover $)^{1 / 3}$ (2)

4. Mapping climatic quality index (CQI): Climatic quality is calculated by using parameters that influence water availability to plants such as the amount of rainfall, air temperature and aridity, as well as climate hazards, which might inhibit plant growth (Thornes, 1995). Table (1) reveals the classification categories of climatic quality index according to MEDELUS approach. In the current study, the climate quality index 
Table 1. ESA quality indices parameters, description, and score used for application of the adjusted MEDELUS approach (After Bakr, et al., 2012)

\begin{tabular}{|c|c|c|c|c|}
\hline $\begin{array}{l}\text { quality } \\
\text { index }\end{array}$ & Parameter & Class & Description & Score \\
\hline \multirow[t]{22}{*}{ SQI } & Texture* & 1 & $\mathrm{~L}, \mathrm{SCL}, \mathrm{SL}, \mathrm{LS}, \mathrm{CL}$ & 1 \\
\hline & & 2 & SC, SiL, SiCL. & 1.2 \\
\hline & & 3 & $\mathrm{Si}, \mathrm{C}, \mathrm{SiC}$ & 1.6 \\
\hline & & 4 & $\mathrm{~S}$ & 2 \\
\hline & Parent & 1 & Shale, schist, Marl, basic, ultra basic, Conglomerates, Unconsolidated & 1 \\
\hline & materials & $\begin{array}{l}2 \\
3\end{array}$ & $\begin{array}{l}\text { Limestone, marble, granite, Rhyolite, Ignibrite, } \\
\text { gneiss, siltstone, sandstone Pyroclastics }\end{array}$ & 1.7 \\
\hline & Slope & 1 & $<6$ & 1 \\
\hline & gradient & 2 & $6-18$ & 1.2 \\
\hline & $(\%)$ & 3 & $18-35$ & 1.5 \\
\hline & & 4 & $>35$ & 2 \\
\hline & Soil depth & 1 & $>75$ & 1 \\
\hline & $(\mathrm{cm})$ & 2 & $30-75$ & 1.2 \\
\hline & & 3 & $15-30$ & 1.5 \\
\hline & & 4 & $<15$ & 2 \\
\hline & Drainage & 1 & Well drained & 1 \\
\hline & status & 2 & Imperfectly drained & 1.2 \\
\hline & & 3 & Poorly drained & 2 \\
\hline & $\mathrm{EC}(\mathrm{dS} / \mathrm{m})$ & 1 & $<1.2$ & 1 \\
\hline & & 2 & $1.2-2.5$ & 1.2 \\
\hline & & 3 & $2.5-4.5$ & 1.5 \\
\hline & & 4 & $4.5-9$ & 1.7 \\
\hline & & 5 & $>9$ & 2 \\
\hline \multirow[t]{3}{*}{ IWQI } & $\mathrm{EC}(\mathrm{dS} / \mathrm{m})$ & 1 & $<0.7$ & 1 \\
\hline & & 2 & $0.7-3$ & 1.5 \\
\hline & & 3 & $>3$ & 2 \\
\hline \multirow[t]{13}{*}{ VQI } & Erosion & 1 & Mixed Mediterranean macchia/evergreen forests & 1 \\
\hline & protection & 2 & Mediterranean macchia, permanent grasslands, evergreen perennial & 1.3 \\
\hline & & 3 & crops Deciduous forests & 1.6 \\
\hline & & 4 & Deciduous perennial agricultural crops & 1.8 \\
\hline & & 5 & Annual agricultural crops, annual grasslands, vines, bare land & 2 \\
\hline & $\begin{array}{l}\text { Drought } \\
\text { resistance }\end{array}$ & 1 & $\begin{array}{l}\text { Mixed Mediterranean macchia/evergreen,forests, Mediterranean } \\
\text { macchia }\end{array}$ & 1 \\
\hline & & 2 & Conifers, deciduous, olives & 1.2 \\
\hline & & 3 & Perennial agricultural trees & 1.4 \\
\hline & & 4 & Perennial grasslands & 1.7 \\
\hline & & 5 & Annual agricultural crops, annual grasslands, bare land & 2 \\
\hline & Plant cover & 1 & $>40$ & 1 \\
\hline & & 2 & $10-40$ & 1.8 \\
\hline & & 3 & $<10$ & 2 \\
\hline \multirow[t]{8}{*}{ CQI } & Rainfall & 1 & $>650$ & 1 \\
\hline & $(\mathrm{mm})$ & 2 & $280-650$ & 1.5 \\
\hline & & 3 & $<280$ & 2 \\
\hline & Aridity & 1 & Humid: $>0.65$ & 1 \\
\hline & $(\mathrm{P} / \mathrm{PET})$ & 2 & Dry sub-humid: $0.50-0.65$ & 1.2 \\
\hline & & 3 & Semi-arid: $0.20-0.5$ & 1.5 \\
\hline & & 4 & Arid: $0.05-2.0$ & 1.7 \\
\hline & & 5 & Hyper-arid $<0.05$ & 2 \\
\hline \multirow[t]{6}{*}{ MQI } & Land use & 1 & Low land use intensity & 1 \\
\hline & intensity & 2 & Medium land use intensity & 1.5 \\
\hline & (cropland) & 3 & High land use intensity & 2 \\
\hline & Policy & 1 & High degree of implementation of environmental protection policies & 1 \\
\hline & & 2 & $\begin{array}{l}\text { Moderate degree of implementation of environmental protection } \\
\text { policies }\end{array}$ & 1.5 \\
\hline & & 3 & Low degree of implementation of environmental protection policies & 2 \\
\hline
\end{tabular}

* Soil Texture Abbreviations: L =Loam; SCL = Sandy Clay Loam; SL = Sandy Loam; LS = Loamy Sand; CL = Clay Loam; SC

$=$ Sandy Clay; $\mathrm{SiL}=$ Silt Loam; $\mathrm{SiCL}=$ Silty Clay Loam; $\mathrm{Si}=$ Silty; $\mathrm{C}=$ Clay; $\mathrm{SiC}=$ Silty Clay; $\mathrm{S}=\mathrm{Sand}$. 
Table 2. Final ESAI indices and classes, description and ranges (After Bakr, et al. 2012)

\begin{tabular}{|c|c|c|c|}
\hline Indices & Quality Classes & Description & Range \\
\hline \multirow{3}{*}{ SQI } & 1 & High quality & $<1.13$ \\
\hline & 2 & Moderate quality & $1.13-1.45$ \\
\hline & 3 & Low quality & $>1.45$ \\
\hline \multirow{3}{*}{ IWQI } & 1 & High quality & $<1$ \\
\hline & 2 & Moderate quality & $1-1.41$ \\
\hline & 3 & Low quality & $>1.41$ \\
\hline \multirow{3}{*}{ VQI } & 1 & High quality & $1-1.13$ \\
\hline & 2 & Moderate quality & $1.13-1.41$ \\
\hline & 3 & Low quality & $>1.41$ \\
\hline \multirow{3}{*}{ CQI } & 1 & High quality & $<1.15$ \\
\hline & 2 & Moderate quality & $1.15-1.81$ \\
\hline & 3 & Low quality & $>1.81$ \\
\hline \multirow{3}{*}{ MQI } & 1 & High quality & $1-1.25$ \\
\hline & 2 & Moderate quality & $1.25-1.5$ \\
\hline & 3 & Low quality & $>1.5$ \\
\hline \multirow{8}{*}{ ESAI } & Critical & $\mathrm{C} 3$ & $>1.53$ \\
\hline & & $\mathrm{C} 2$ & $1.41-1.53$ \\
\hline & & $\mathrm{C} 1$ & $1.37-1.41$ \\
\hline & Fragile & F3 & $1.32-1.37$ \\
\hline & & $\mathrm{F} 2$ & $1.26-1.32$ \\
\hline & & $\mathrm{F} 1$ & $1.22-1.26$ \\
\hline & Potential & $\mathrm{P}$ & $1.17-1.22$ \\
\hline & Non-affected & $\mathrm{N}$ & $<1.17$ \\
\hline
\end{tabular}

is evaluated through the Aridity Index (AI) and the annual precipitation, in accordance with equation (3) for $\mathrm{AI}$ and the final CQI was calculated as shown in equation (4).

$\mathrm{AI}=\mathrm{P} / \mathrm{PET}$----- (3)

where: $\mathrm{P}$ is average annual precipitation and PET is average annual Potential Evapotranspiration.

$\mathrm{CQI}=(\text { rainfall } \times \text { aridity })^{1 / 2}$

5. Mapping management quality index (MQI): The land was classified in different categories according to the major land use for assessing the management quality or the degree of human induced stress. After defining the type of land use in a certain piece of land, the intensity of land use and the enforcement of policy on environmental protection were assessed for the particular type of land use. According to score for each parameter as shown in table (1), MQI was calculated based on equation (5).

MQI $=(\text { land use intensity } \times \text { policy })^{1 / 2}$

6. Mapping Environmentally Sensitivity Area Index (ESAI): ArcGIS 10.1 software was used to map ESA's to desertification by integrating all data concerning the soil, irrigation water, vegetation, climate and management. Different quality indices were calculated and displayed as GIS ready maps from which class areas were deduced as shown in table (2). The adjusted MEDALUS approach equation was:
$\mathrm{ESAI}=(\mathrm{SQI} \times \mathrm{CQI} \times \mathrm{VQI} \times \mathrm{MQI} \times \mathrm{IWQI})^{1 / 5}$

Coupling Geostatistics to GIS: The estimates from Kriging, and the associated error (Gamma Design, Inc. 2002) were formatted, then exported to ArcGIS 10.1 software (ESRI, 2012) for better visualization and output.

\section{RESULTS AND DISCUSSION}

Statistical soil parameters: Table (3) shows the descriptive statistical analysis which indicated that the soil depth ranged from 60 to $120 \mathrm{~cm}$ due to the high water table in the southern part of the study area. Soil salinity varied from 0.72 to $19.60 \mathrm{dS} / \mathrm{m}$ and SAR ranged from 0.80 to 25.20. Soil salinity shows highest coefficient of variation ( 0.92$)$, followed by SAR (0.61), which indicate that less homogeneity in the study area may be due to the different irrigation resources and qualities (coefficient of variation for irrigation water salinity $=0.97)$.

Terrain analysis: The Digital Elevation Model (DEM) indicated that the elevations varied from 1 to $6 \mathrm{~m}$ A.S.L. The eastern part of the study area has the lowest elevation, ranged from 1 to $2 \mathrm{~m}$ A.S.L. It is noticeable that the north facing directions $(\mathrm{N}, \mathrm{NE}, \mathrm{NW})$ is the dominant aspect, followed by the south facing directions (S, SE, SW). 
Table 3. Descriptive statistical analysis of soil and irrigation water parameters

\begin{tabular}{|c|c|c|c|c|c|}
\hline Parameters & Soil depth, cm & Soil salinity. dS/m & SAR & Clay, \% & $\begin{array}{c}\text { Irrigation water } \\
\text { salinity, ds/m }\end{array}$ \\
\hline $\mathrm{N}$ of Cases & 85 & 85 & 85 & 85 & 85 \\
\hline Minimum & 60.00 & 0.72 & 0.80 & 11.25 & 0.4 \\
\hline Maximum & 120.00 & 19.06 & 25.20 & 57.51 & 8.6 \\
\hline Range & 60.00 & 18.34 & 24.40 & 46.26 & 8.2 \\
\hline Median & 120.00 & 2.29 & 5.66 & 37.00 & 0.75 \\
\hline Arithmetic Mean & 113.88 & 2.78 & 6.44 & 36.91 & 1.35 \\
\hline Standard Deviation & 13.19 & 2.56 & 3.91 & 9.17 & 1.31 \\
\hline Coefficient of Variation & 0.12 & 0.92 & 0.61 & 0.25 & 0.97 \\
\hline $\begin{array}{l}\text { Semi-Variogram of the so } \\
\text { Semivariograms of in } \\
\text { itted to two models. Soil } \\
\text { itted to the Gaussian mode } \\
\text { itted to the Spherical mod } \\
\text { oarameters of these model }\end{array}$ & $\begin{array}{l}\text { roperties: } \\
\text { lual soil proper } \\
\text { inity and soil de } \\
\text { AR and clay con } \\
\text { s shown in figure } \\
r \text { different soil }\end{array}$ & \multicolumn{4}{|c|}{$\begin{array}{l}\text { variance }(15.10) \text { which reflects strong spatial } \\
\text { dependence and high inherited variability according to } \\
\text { (Xu and Webster, } 1984 \text { and Warrick, et. al., 1986). On } \\
\text { the other hand, soil depth and soil salinity have the } \\
\text { lowest nugget variance that reflects weak spatial } \\
\text { dependence and high homogeneity. }\end{array}$} \\
\hline
\end{tabular}

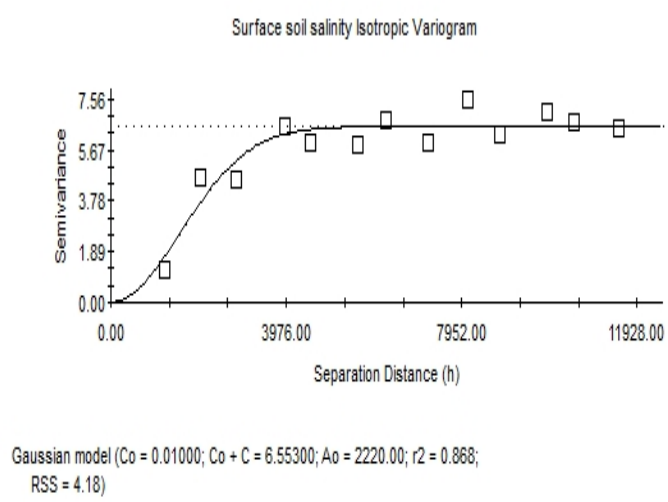

Gaussian model $\left(C_{0}=0.01000 ; C_{0}+C=6.55300 ; A 0=2220.00 ; 12=0.868\right.$;
RSS $=4.18)$

Surface clay Isotropic Variogram

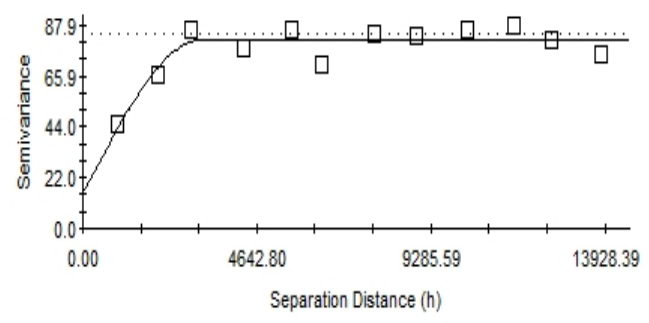

Spherical model $\left(C_{0}=15.10000 ; C_{0}+C=81.69000 ; A 0=3180.00 ; r 2=0.820 ;\right.$ RSS $=293$.)
Soil depth Isotropic Variogram

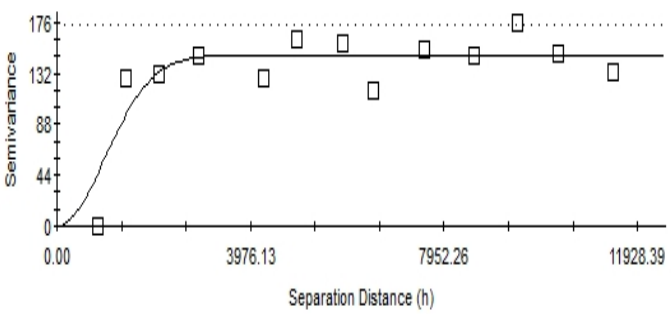

Gaussian model $\left(C_{0}=0.10000 ; C_{0}+C=147.50000 ; A 0=1380.00 ; r 2=0.775\right.$ RSS $=5713$.)

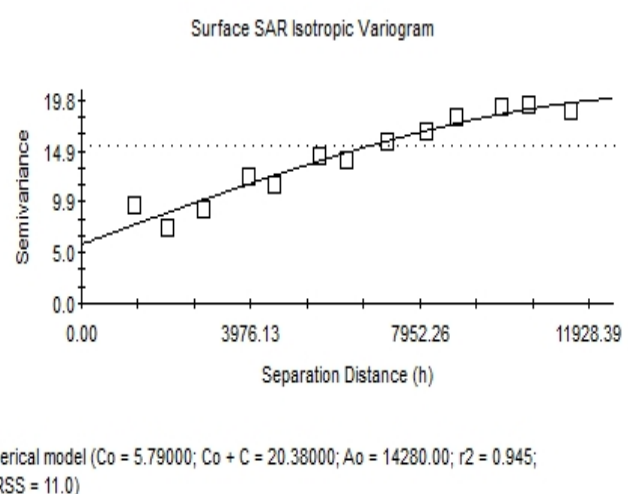

Fig. 2. Isotropic semi-variogram related to soil properties using Kriging method for surface layer 
Table 4. Variogram models of soil characteristics and their parameters

\begin{tabular}{lccccc}
\hline Soil Property & Model & Nugget $\left(\mathbf{C}_{\mathbf{0}}\right)$ & Sill $\left(\mathbf{C}+\mathbf{C}_{\mathbf{0}}\right)$ & Range effect, $\mathbf{m}(\mathbf{A o})$ & $\mathbf{R}^{\mathbf{2}}$ \\
\hline EC $(\mathrm{dS} / \mathrm{m})$ & Gaussian & 0.01 & 6.553 & 2220 & 0.87 \\
SAR & Spherical & 5.79 & 20.38 & 14280 & 0.95 \\
Soil depth, cm & Gaussian & 0.10 & 147.50 & 1380 & 0.76 \\
Clay, $\%$ & Spherical & 15.10 & 81.69 & 3180 & 0.82 \\
\hline
\end{tabular}

\section{Soil thematic maps:}

a) Salinity: Map (3) shows the distribution of the soil salinity of the surface soil samples. It is clear that salinity is highly variable and ranged from $<2$ to $19.70 \mathrm{dS} / \mathrm{m}$. The dominant soil salinity range ( 2.1 to $4 \mathrm{dS} / \mathrm{m}$ ) covers about $54.41 \%$ of the total area followed by the range $(0.5$ to $2 \mathrm{dS} / \mathrm{m})$ which covers about $24.75 \%$ of the total area.

b) Sodium Adsorption Ratio (SAR): Map (4) shows the distribution of SAR in the study area, which ranged from 2 to 14 . It's clear that the dominant class varied from 4 to 8 and located in the north and south parts of the study area.

c) Clay Content: Map (6) shows the distribution of clay content in the study area. The results show that clay content ranged from 18 to $50 \%$. The dominant clay content percentage was 30 to $40 \%$ followed by 40 to $50 \%$ which covers the middle and southwestern parts of the study area.

d) Soil Depth: Map (5) shows the soil depth distribution in the study area using Kriging method. The results show that the soil depth ranged from moderately deep $(60 \mathrm{~cm})$ to deep $(126 \mathrm{~cm})$. It is clear that the

dominant soil depth class were deep and prevalent in all the study area.

Soil Quality Index (SQI): According to the geologic map of Egypt, previous studies and field trips to the study area showed that the dominant parent material is soft to friable alluvium. The soil depth was measured in the field, and shows that the soil is characterized by moderately deep to deep soil depth. The mechanical analysis of the soil samples showed that the dominant soil texture class was clayey. The slope gradient was classified, on basis of the data obtained from digital elevation model (DEM). Calculating the soil quality index reveals that the majority of the study area was characterized by high quality $(<1.13)$ and the rest of the area had moderate quality (score ranged from 1.13 to 1.45).

Irrigation Water Quality Index (IWQI): The index ranged from high quality class $(<1)$ to low quality class $(>1.41)$, which indicate that less homogeneity in the study area may be due to the different irrigation resources, qualities, and many point sources of pollution

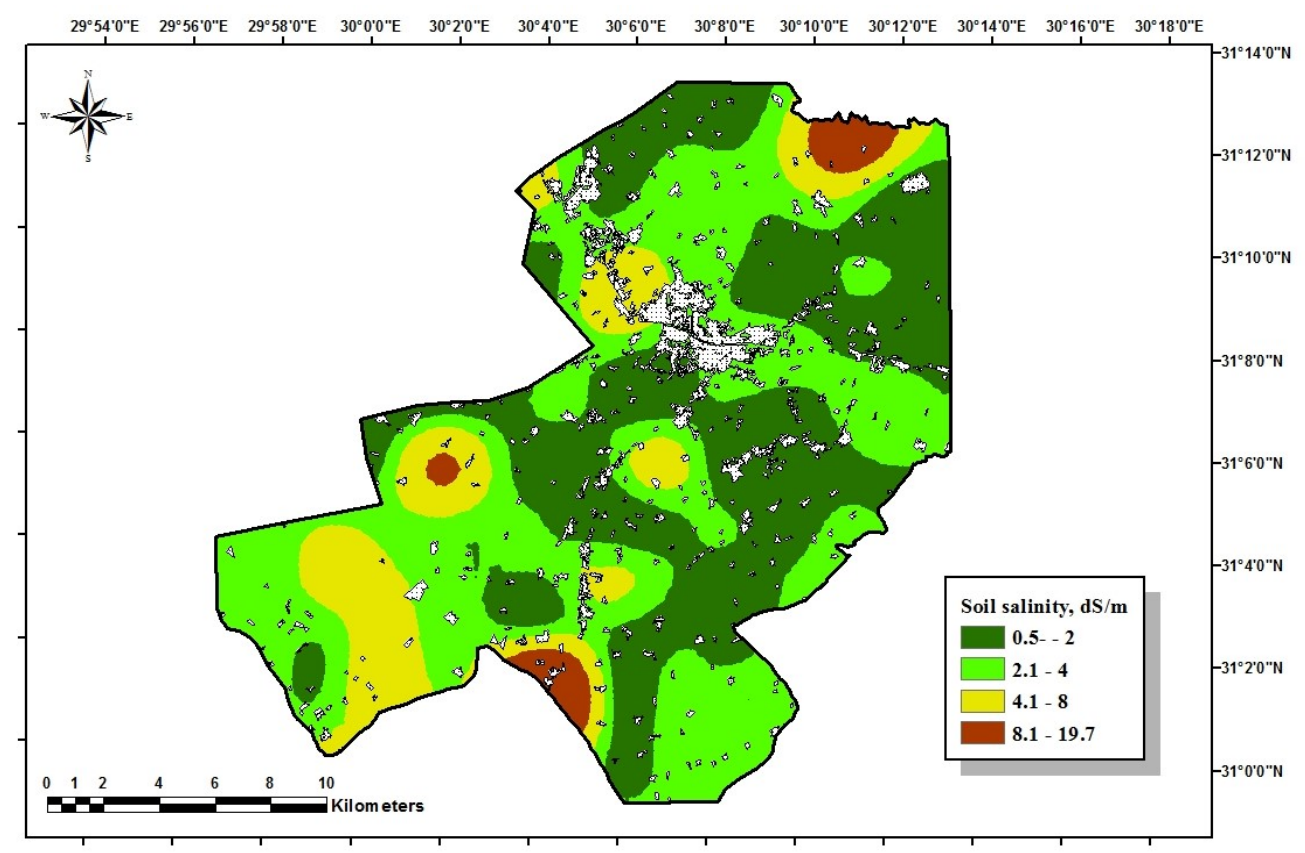

Map 3. Spatial distribution of soil salinity (dS/m) using Kriging method for surface layer 


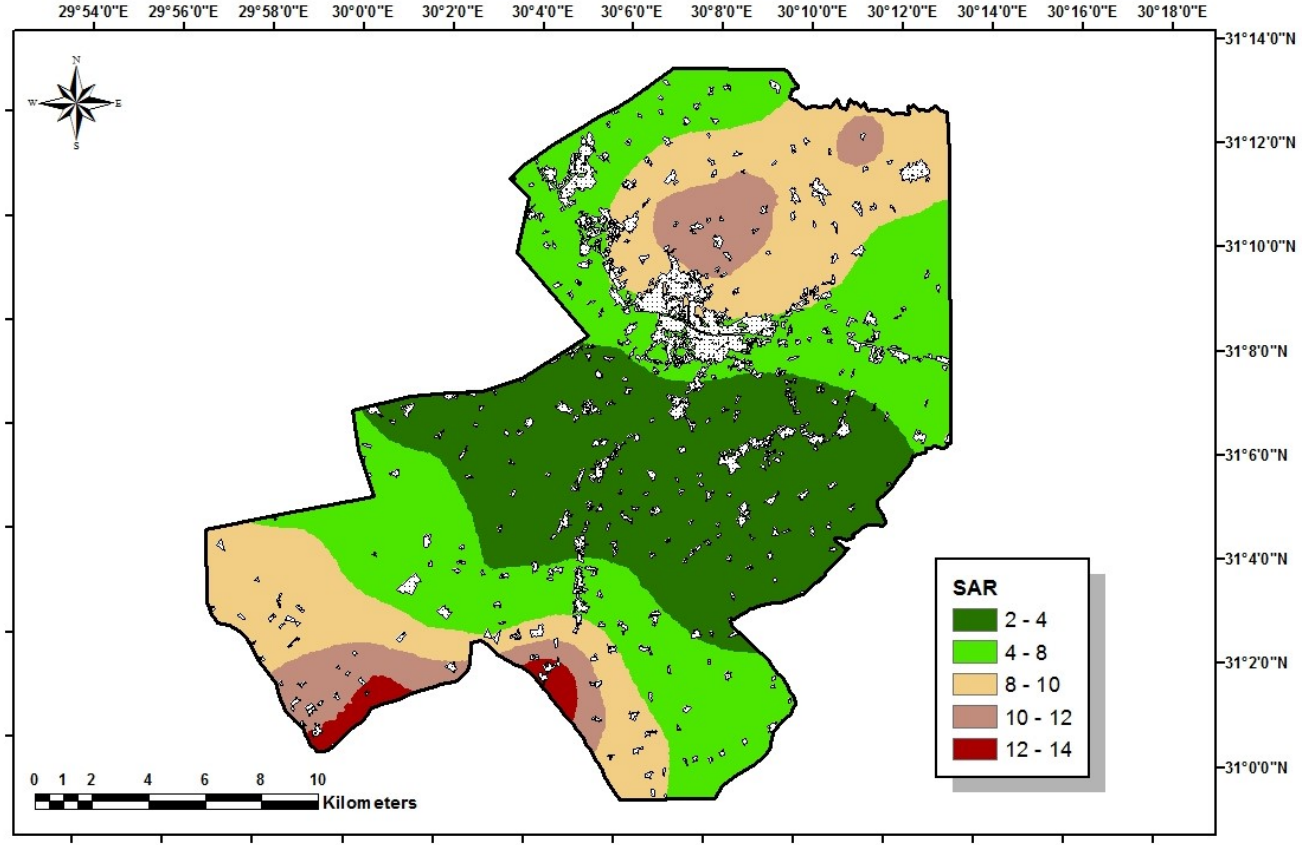

Map 4. Spatial distribution of SAR using Kriging method for surface layer

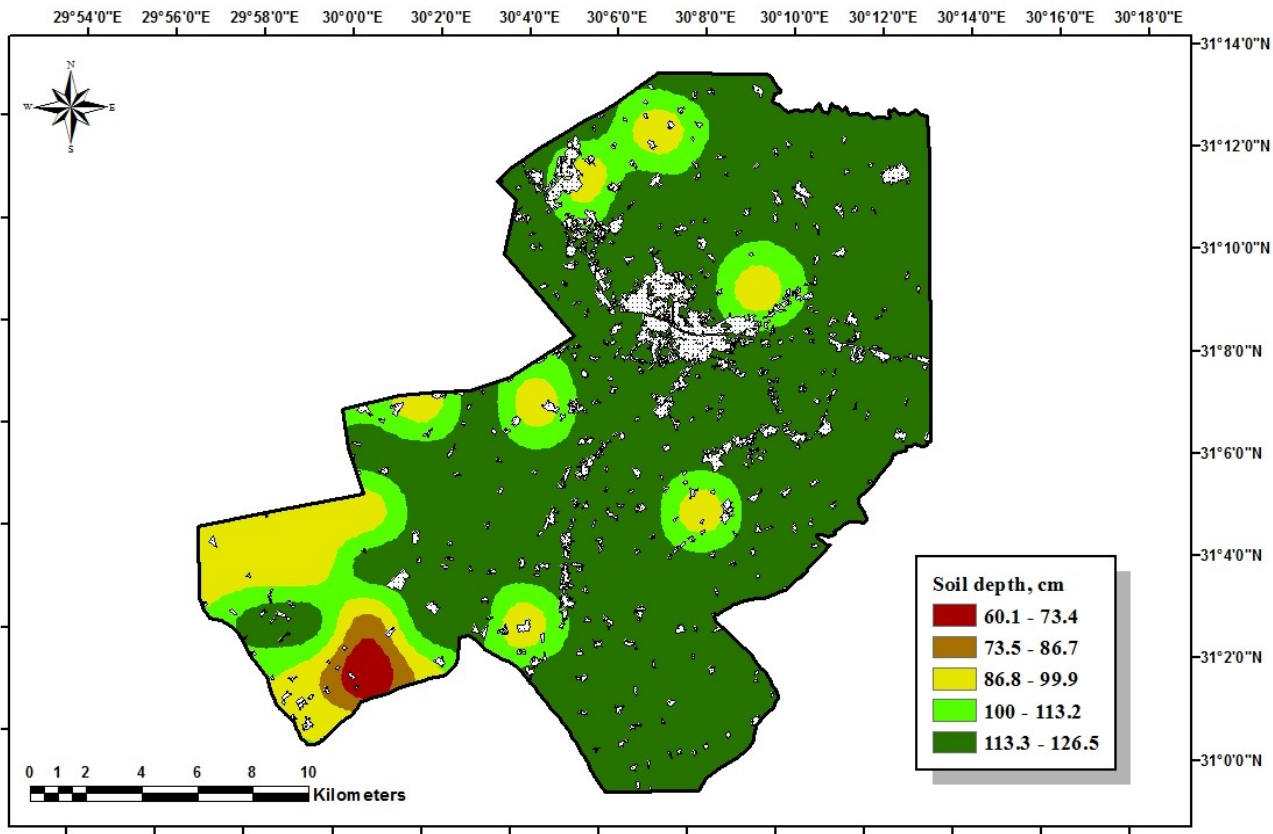

Map 5. Spatial distribution of Soil depth, $\mathrm{cm}$ using Kriging method for the study area

Vegetation Quality Index (VQI): Data collected from the field trip and the questionnaires identified that the vegetation pattern was annual agricultural crops. Vegetation quality index was given a score evaluating vegetation cover, erosion protection and drought resistance. The calculated vegetation quality index was 1.13 , which indicated that the VQI of study area was on the border between high and moderate quality classes.
Climate Quality Index (CQI): The climatic sensitivity index was calculated and stored in a GIS, as it was constant across the study area (1.73). The semi-arid climatic conditions characterize the study area.

Management Quality Index (MQI): Kafr El Dawar is a major industrial and municipality city at the western part of Nile Delta. MQI in the study area was categorized as the low management quality class where 
no sustainable management strategies were applied. Intensive agriculture existed and extensive and unbalanced use of fertilizers and pesticides were considered.

Environmentally Sensitivity Area Index (ESAI): The ESAIs was calculated based on the overlaying technique of the different quality indices, which allows identifying the links between those indices and their spatial patterns. Table (5) shows the areal coverage of the ESAI for the study area. The results showed that $3.24 \%$ of the study area is critical to desertification, whereas $3.12 \%$ are fragile to desertification. Map 7 displays the spatial distribution of ESAI over the study area. The results show that most of the study area $(92.72 \%)$ was Nonaffected to desertification. The low quality classes of the ESAI were located at the southwestern part of the study area which irrigated by low quality water. The results elucidate that the distribution of ESAI classes matched with the soil characteristics distribution maps which used to calculate the SQI (maps 3 to 6).

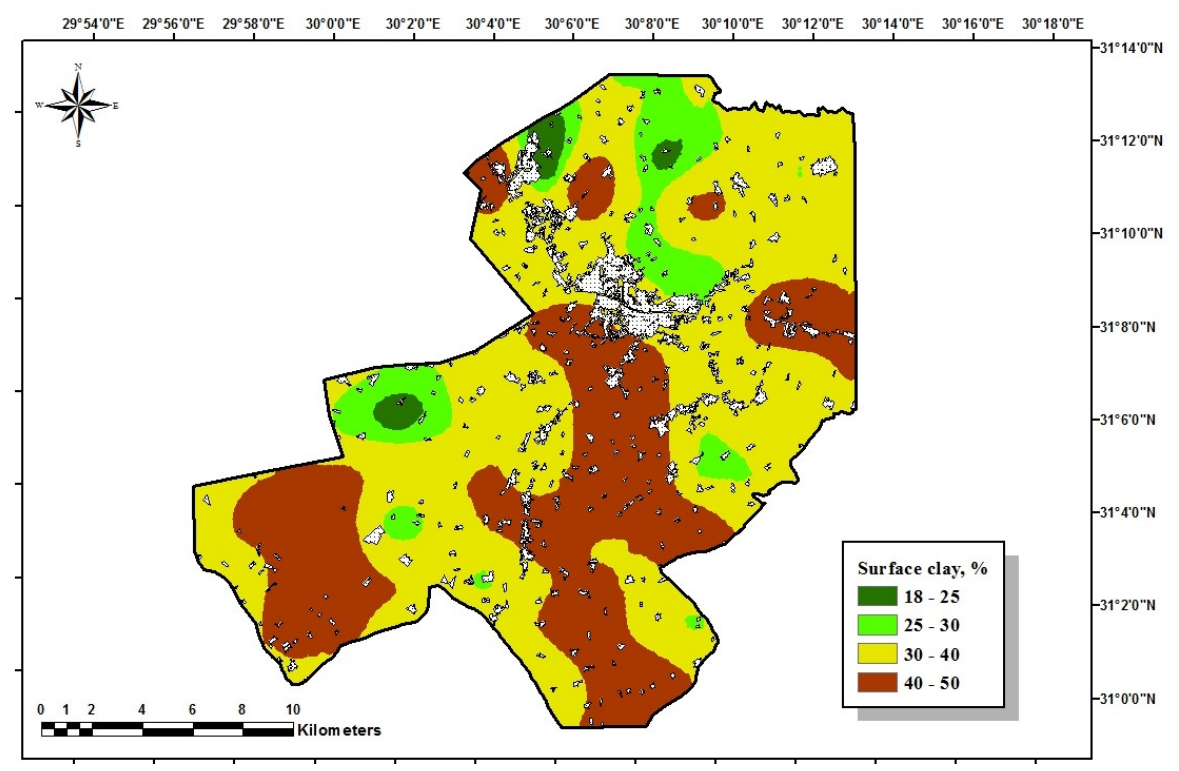

Map 6. Spatial distribution of clay (\%) using Kriging method for surface layer

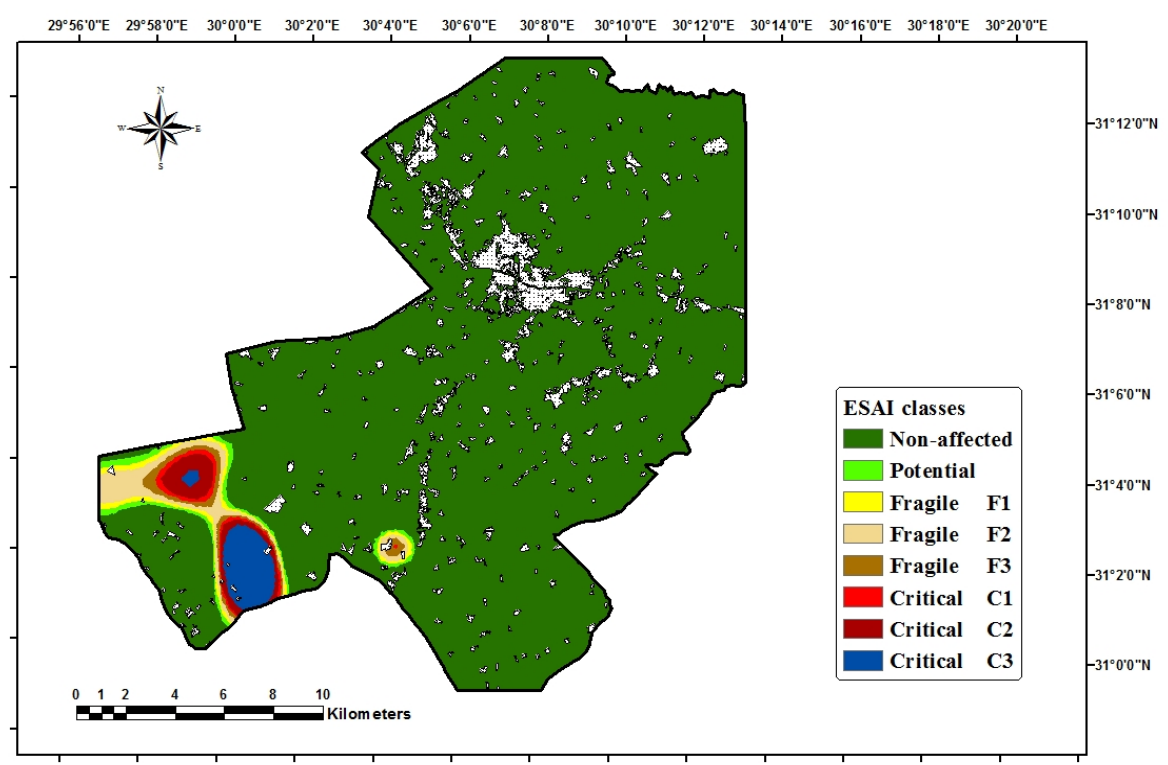

Map 7. Spatial distribution of ESAI for the study area 
Table 5. The area of ESAI classes in the study area

\begin{tabular}{lcccc}
\hline Class & Sub-class & Area (ha.) & Area (\%) & Total \\
\hline Critical & C1 & 598.68 & 1.65 & 3.24 \\
& C2 & 412.25 & 1.13 & \\
Fragile & C3 & 167.74 & 0.46 & 3.12 \\
& F1 & 282.25 & 0.78 & 1.55 \\
Fotential & F3 & 565.46 & 0.79 & 0.92 \\
Non-affected & P & 290.03 & 92.72 & 100 \\
Total & N & 332.76 & 3321.70 & \\
\hline
\end{tabular}

\section{CONCLUSIONS}

The results obtained from this study showed that soil quality, irrigation water quality, management, and plant cover dramatically impact desertification processes. Most of the study area was Non-affected by desertification. The low quality classes of the ESAI were located at the southwestern part of the study area. The integration of GIS and geostatistical analysis of soil characteristics could provide a superior database and guide map to calculate and classify ESAI.

The assessment of environmental sensitive areas to desertification by coupling geostatistical analysis with modeling in geographic information system can be used as effective tool to help decision-makers involved in the planning of sustainable land uses to identify and resist the desertification hazards. Thus, decision-makers should give more attention to the sensitive areas to desertification. The study recommended that the quantitative approach to assess the sensitivity to desertification should be adopted and applied for the areas were desertification and environmental deterioration is expected and considered. Choosing the suitable spatial and temporal scales, as well as identifying the appropriate parameters, and using appropriate models are essential for correctly identifying and monitoring the ecosystem over long periods of time, to assess the sensitivity to desertification and sustainable land use planning.

\section{REFERENCES}

Bakr, N., D. Weindorf, M. Bahnassy, and M. El-Badawi. 2012. Multi-temporal assessment of land sensitivity to desertification in a fragile agro-ecosystem: Environmental indicators. Ecol. Indicat. 15, 271-280

Basso F., A. Bellotti, E. Bove, S. Faretta, A.Ferrara, G.Mancino, M. Pisante, G.Quaranta, and M. Taberner . 1998. Degradation processes in the Agri Basin: evaluating environmental sensitivity to desertification at basin scale. Proceedings International Seminar on 'Indicator for Assessing Desertification in the Mediterranean'. Porto Torres, Italy 18 - 20 September. Edited by G. Enne, M.

Briggs D., A. Giordano, M. Cornaert, D. Peter, and J. Maef. 1992. CORINE soil erosion risk and important land resources in the southern regions of the European Community. EUR 13233. Luxembourg. 97 pp.

Burgess, T.M. and R. Webster.1980. Optimal interpolation and isarithmic mapping of soil properties. Europ. J. Soil Sci.31 (2): 331-341.

ESRI. 2012. ArcGIS 10.1 user,s manual. Redlands, CA, USA.

European Commission. 1999. The Medalus project Mediterranean desertification and land use- Manual on key indicators of desertification and mapping environmentally sensitive areas to desertification, pp. 84, Eds. C. kosmas, M. Kirkby and N. Geeson, European environment and climate research program - Theme: Land resources and the threat of desertification and soil erosion in Europe (Project ENV4 CT 95 0119).

FAO. 2007. Mapping land degradation and sustainable land management. In LADA project publication, Liniger $\mathrm{H}$, van Lynden G, Nachtergaele F (eds). Food and Agriculture Organization of the United Nations: Rome.

Gamma Design Inc. 2002. GS+ Ver.5.3a Geostatistical software user manual. Plainwell, Michigan, USA.

Geist H. 2005. The causes and progression of desertification. Ashgate Publishing Company: Aldershot.

Goovaerts, P. 1997. Geostatistics for natural resources evaluation. Oxford University Press.

Hill J, M. Stellmes , T. Udelhoven , A. Röder , and Sommer. 2008. Mediterranean desertification and land degradation. Mapping related land use change syndromes based on satellite observation. Global and Planetary Changes 64(3-4): 146-157.

Klute, A. (ed.). 1986. Methods of soil analysis. Part 1 Physical and mineralogical methods. 2nd ed. SSSA Book Series No. 5. SSSA and ASA, Madison, WI.

Kosmas, C., A. Ferrara, H. Briasouli, and A. Imeson.1999. Methodology for mapping environmentally sensitive areas (ESAs) to desertification. In: Kosmas, C., Kirkby, M., Geeson, N. (Eds.), The Medalus Project: Mediterranean Desertification and Land Use.Manual on Key Indicators of Desertification and Mapping Environmentally Sensitive Areas to Desertification. European Union 18882.

Kosmas, C., M. Tsara, N. Moustakas, and C.Karavitis.2003. Identification of indicators for desertification. Ann. Arid Zones 42, 393-416. 
Page, A. L. 1982. Methods of Soil Analysis. Part Chemical and Microbiological Properties, Second Edition. Managing Editor, R. C. Dinauer.

Raissouni A., L. Issa, A. El Arrim , M. Maâtouk, and R. Passalacqua . 2012. GIS-Based Model to Assess Erosion Sensitivity in Northern Morocco. Laou Watershed Case Study. International Journal of Geosciences, 3, 610-626

Salvati L, and M. Zitti . 2008. Regional convergence of environmental variables: empirical evidences from land degradation. Ecological Economics 68(1): 162-168.

Santini M, G. Caccamo, A. Laurenti , S. Noce , and R. Valentini . 2010. A multi-component GIS framework for desertification risk assessment by an integrated index. Applied Geography 30(3): 394-415.

Thornes J.B. 1995. Mediterranean desertification and the vegetation cover. In EUR 15415 - "Desertification in a European context: Physical and socio-economic aspects", edited by R.Fantechi, D.Peter, P.Balabanis, J.L. Rubio. Brussels, Luxembourg: Office for Official Publications of the European Communities. 169- 194

Wagner Lourenco R, P.M.P.Landim, R.A.Henrique , J.A.F.Roveda , A.C.G.Martins, and L.F.Fraceto . 2010. Mapping soil pollution by spatial analysis and fuzzy classification. Environ Earth Sci 60: 495-504

Warrick, A. W, D. E. Mers, and D. R. Nielsen. 1986. Geostatistical methods applied to soil science. In A. Klute (ed) Methods of soil analysis. Part 1: Physical and Mineralogical Methods. Z nd ed. Agronomy 9: 53-81.

Webster, R. 1977. Quantitative and numerical methods in soil classification and survey. Clarendon press, Oxford.

Wessels K.J, S.D.Prince , J.Malherbe , J.Small ,P.E. Frost , and Z.D. Van .2007. Can human-induced land degradation be distinguished from the effects of rainfall variability? A case study in South Africa. Journal of Arid Environments 68(2): 271-297.

Wilding, L.P. and L.R. Drees. 1983. Spatial variability and pedology. pp.83-116. In: L.P. Wilding et al. (eds). Pedogenesis and soil taxonomy. 1:concepts and interpretation. Elsevier, Amsterdam.

Xu, J. and R. Webster. 1984. A geostatistical study of top soil properties Lin Zhangwu country. China Catena 11, 13-26.

Yehia, H. A., R.I. Fayed, and K.A. Rateb. 2013. Integration of GIS and Modeling to Study Soil Characterization, Evaluation and Sensitivity to Degradation of some Alluvial Deposits, Egypt. Alexandria Science Exchange Journal, Vol.34, No.4. 460-475.

Zucca C., R. Biancalani ,S. Kapur, E. Akça , P. Zdruli, L. Montanarella, and F. Nachtergaele . 2014. The Role of Soil Information in Land Degradation and Desertification Mapping: A Review. In: S. Kapur and S. Ersahin (eds.), 2014. Soil Security for Ecosystem Management. Springer, pp 31-59. 


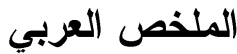

التحليل المكانى لخواص التربه وحساسيتها للتصحر لبعض الار اضى الرسوبيه بمحافظة البحيرة - مصر على عبد المجيد جعفر، ايهاب محرم مرسى، هيثم محمد يحيى

الرو ابط بين تلك الدلائل و أنماطها المكانية. وقـــد أظهـرت

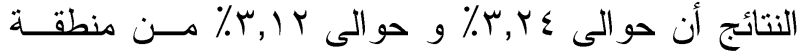
الدراسة نم تصنيفها على أنها فئة حرجة وفئة اقل خطـــوره

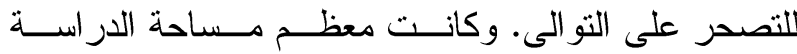

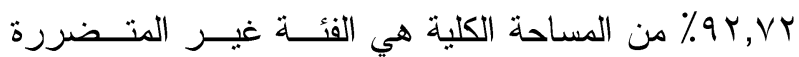
للتصحر. وكانت الفئات منخفضة الجوده لدليل الحسساسية البيئيه للتصحر تقع في الجزء الجنوبي الغربي من منطقـــة الدراسة. وأوضحت النتائج أن توزيع يليل الحساسية البيائية

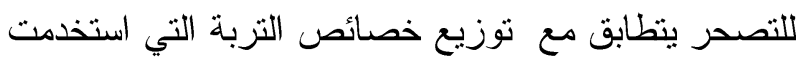

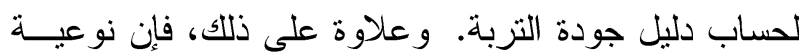

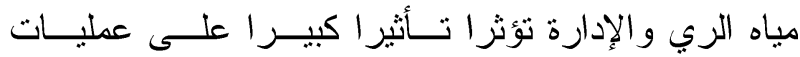

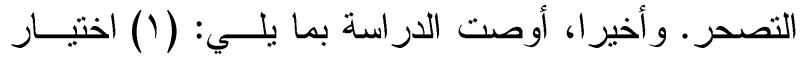

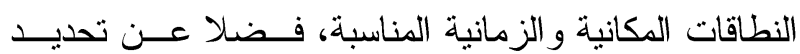
الخصائص و العو امل المناسبة، واستخدام النماذج المناســبة

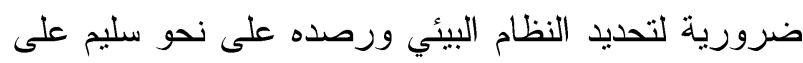

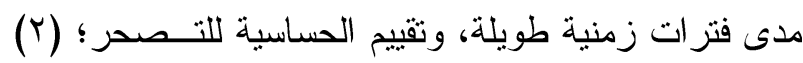

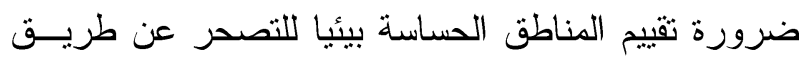

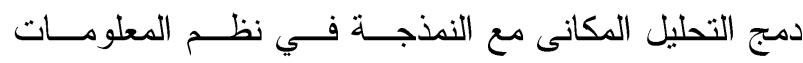

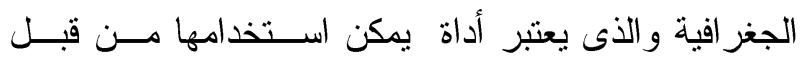

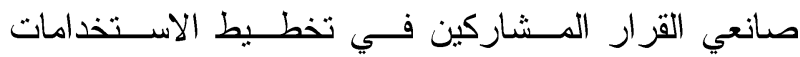
المستدامة للأر اضي لتحديد ومقاومة مخاطر التصحر .
هدفت هذه الدراسة إلى استخدام الطريقة الكمية لتقيــيم

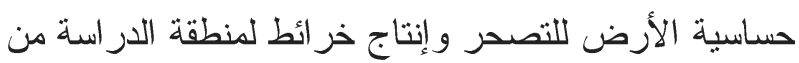

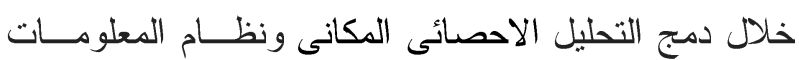

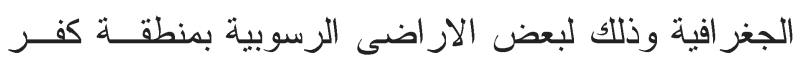

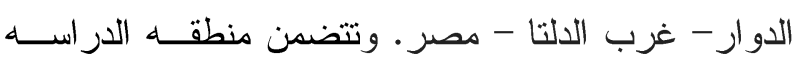

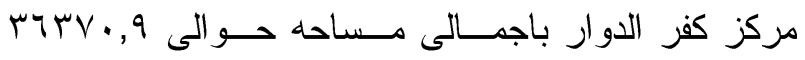

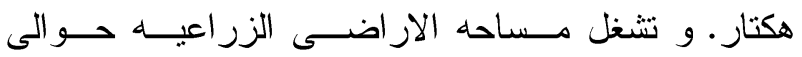

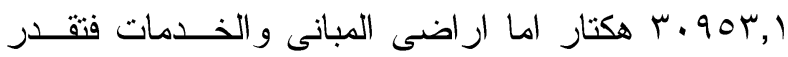

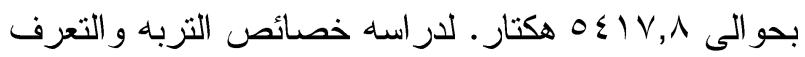

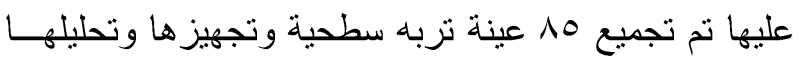

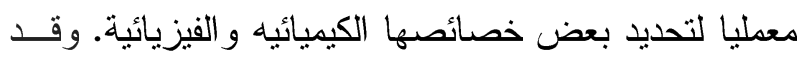
أجري التحليل الاحصائى المكانى لرسم خرائط خصائص التربة في بيئة نظم المعلومات الجغر افيــة. ومــن خــلال

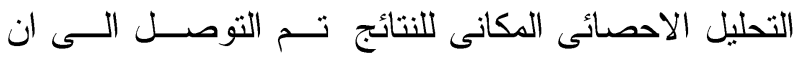

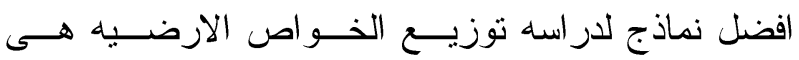

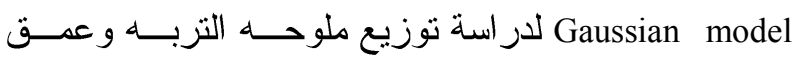

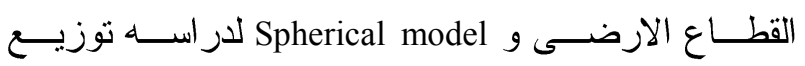
نسبةالصوديوم المدمص ونسبة الطين بالتربه. ومن خــلال The Environmental دراسة و حساب دليل الحساسية البيئية Sensitivity Index (ESAI)

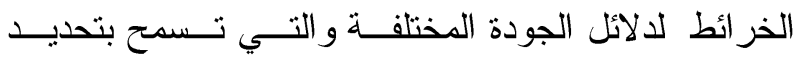

